\title{
The origin of the Pycnodonteinae and relationship between gryphaeas and true pycnodontes
}

\author{
Igor N. Kosenko \\ Acta Palaeontologica Polonica 63 (4), 2018: $769-778$ doi:https://doi.org/10.4202/app.00494.2018
}

Berriasian (Early Cretaceous) oyster Pycnogryphaea weberae from Crimea is one of the earliest known pycnodonteine oysters. Examination of shell morphology and microstructure of this species shows that it shares characters of the subfamilies Gryphaeinae and Pycnodonteinae. Shell microstructure of Pycnogryphaea weberae lacks vesicular structure and is similar to microstructure of the genus Gryphaea. At the same time the shell of this species possesses morphological characters typical of pycnodonteins: development of chomata and well-defined circumferential curb. Pycnogryphaea weberae is regarded as a transitional taxon between the subfamilies Gryphaeinae and Pycnodonteinae and referred herein to a new genus Pycnogryphaea within the Pycnodonteinae. This suggests that the subfamily Pycnodonteinae likely originated from the Late Jurassic representatives of the genus Gryphaea (Gryphaeinae) in Berriassian. First pycnodonteins preserved shell microstructure of the genus Gryphaea but developed chomata along all the perimeter of both valves.

Key words: Bivalvia, Gryphaeinae, Pycnodonteinae, Cretaceous, Berriasian, Crimea.

Igor N. Kosenko [kosenkoin@ipgg.sbras.ru], Trofimuk Institute of Petroleum Geology and Geophysics, Novosibirsk, 630090, Russia; correspondence address: Prospekt Koptyuga, 3, Novosibirsk, 630090, Russia; Novosibirsk State University, Novosibirsk, 630090, Russia.

This is an open-access article distributed under the terms of the Creative Commons Attribution License (for details please see creativecommons.org), which permits unrestricted use, distribution, and reproduction in any medium, provided the original author and source are credited. 
Fof Full text $(917.3 \mathrm{kB})$ 